\title{
PENERAPAN VIDEO SENAM KESEGARAN JASMANI 2012 UNTUK MENINGKATKAN GERAKAN SENAM KESEGARAN JASMANI SISWA KELAS V SD NEGERI 1 PANGGUNG BARAT MAGETAN
}

\author{
Titin Kuntum Mandalawati *
}

\begin{abstract}
This research purposes to improve the movements of the fifth graders of the elementary school SD Negeri 1 Panggung Barat Magetan by applying the Gymnastic Video of "SenamKesegaranJasmani (SKJ)" 2012. This is a Classroom Action Research (CAR). The source of data are the fifth graders of SDN I Panggung Barat Magetan as many as 30. Data were collected through tests and observation. They are qualitatively described and the percentage of the distribution is provided. Results show that applying the SKJ video improved the movements of the fifth graders of SDN I Panggung Barat Magetan as indicated by the tests on their movements before and after the application of the video. The descriptive qualitative analysis improvements were visible on the cycle I, II and III in which there were three action meetings. In the first cycle it focused on the warming up, core and cooling-down movements. In the final meeting of the first cycle, a test was administered. In the first cycle it found improvement of $30 \%$ out of the 30 students i.e. 9 students. In the second cycle was reflection on the first cycle and another movement was added. In this cycle the emphasis was on the core movements and repeating the warming up and introducing the cooling-down ones. In thi final meeting of this cycle, a test was administered and all students took part. The second cycle witnessed improvement of 60\%, 19 out of 30 students. The third cycle was a reflection on the second cycle in addition to another movement introduction. This cycle emphasized on the cooling-down movements and repetition on the warming up and core movements. In the final meeting, a test was administered to know whether or not the students improved. All of them participated. In this cycle it was found improvement of $75 \%$, or 23 out of 30 students. However, there were 25 of them who could perform correctly. The percentage, therefore, changes into $80 \%$. This is higher than the expected one on the third cycle. It is also revealed that $19.4 \%$ or 6 students were not able to perform the gymnastic correctly.
\end{abstract}

Key words: SKJ 2012 Video, Gymnastic Movements

\begin{abstract}
Abstrak
Tujuan penelitian adalah untuk meningkatkan gerakan Senam Kesegaran Jasmani (SKJ) dengan penerapan video SKJ 2012 siswa kelas V SD Negeri 1 Panggung Barat Magetan. Penelitian ini
\end{abstract}

\footnotetext{
* Titin Kuntum Mandalawati adalah Dosen Prodi PGSD FIP IKIP PGRI MADIUN
} 
menggunakan metode Penelitian Tindakan Kelas (PTK). Sumber data dalam penelitian ini adalah siswa kelas V SDN 1 Panggung Barat Magetan berjumlah 30 siswa. Teknik pengumpulan data dengan tes penilaian SKJ 2012 dan observasi. Teknik analisis data yang digunakan dalam penelitian ini adalah secara deskriptif kualitatif dan persentase yang didasarkan data hasil tes SKJ 2012 yang dilakukan oleh siswa. Berdasarkan hasil penelitian diperoleh simpulan yaitu penerapan video SKJ 2012 dapat meningkatkan gerakan SKJ siswa kelas V SD Negeri 1 Panggung Barat Magetan. Dari hasil analisis data tes SKJ 2012 yang dilaksanakan untuk mengetahui peningkatan gerakan SKJ 2012 secara benar dilakukan sebelum dan sesudah pelaksanaan siklus. Dari hasil analisis data secara deskriptif kualitatif diperoleh peningkatan gerakan SKJ 2012 pada siklus I, II, dan III, setiap siklus terdapat tiga pertemuan tindakan. Pada siklus I pembelajaran SKJ 2012 penekanan pada gerakan pemanasan dengan pengenalan gerakan inti dan pendinginan, pada akhir pertemuan siklus I diadakan uji keterampilan oleh siswa dalam melakukan SKJ 2012 secara keseluruhan. Diketahui pada siklus I ini mencapai tingkat keberhasilan sebesar 30\% dari 30 siswa yaitu sebanyak 9 siswa. Pada siklus II pembelajaran SKJ 2012 merupakan refleksi dari siklus I terdapat penambahan materi pada SKJ 2012. Pembelajaran SKJ 2012 pada siklus II ini penekanan pada gerakan inti SKJ 2012 dengan mengulang gerakan pemanasan dan pengenalan gerakan pendinginan SKJ 2012, untuk mengetahui peningkatan gerakan maka di akhir pertemuan siklus II ini diadakan uji keterampilan yang dilakukan oleh siswa dalam pelaksanaan SKJ 2012 secara keseluruhan. Diketahui dalam siklus II ini mencapai tingkat keberhasilan sebesar 60\% dari 30 siswa yaitu sebanyak 19 siswa. Pada siklus III pembelajaran SKJ 2012 merupakan refleksi siklus II yang terdapat penambahan materi pada SKJ 2012. Pada siklus III ini penekanan pada gerakan pendinginan SKJ 2012 dengan mengulang gerakan pemanasan dan inti SKJ 2012, untuk mengetahui peningkatan gerakan maka diakhir pertemuan siklus III ini diadakan uji keterampilan yang dilakukan oleh siswa dalam pelaksanaan SKJ 2012 secara keseluruhan. Diketahui dalam siklus III ini mencapai tingkat keberhasilan sebesar $75 \%$ dari 30 siswa yaitu sebanyak 23 siswa. Tetapi saat penilaian SKJ 2012 setelah pelaksanaan siklus yang berhasil mempraktikkan gerakan SKJ 2012 secara benar dan hafal menjadi 25 siswa. Sehingga persentase capaian menjadi $80 \%$ dari 30 siswa, lebih tinggi dari persentase capaian yang telah direncanakan pada siklus III. Dalam pelaksanaan PTK yang diakhiri dengan tes SKJ 2012 untuk mengetahui peningkatannya terdapat siswa yang masih belum berhasil dalam penguasaan gerakan SKJ 2012. Dari 30 siswa masih terdapat 6 siswa yang belum berhasil dalam SKJ 2012, dimana persentase dari jumlah siswa yaitu 19,4\% yang belum berhasil melakukan SKJ 2012 secara benar.

Kata Kunci: Video SKJ 2012, Gerakan Senam 


\section{A. PENDAHULUAN}

Pendidikan jasmani merupakan pendidikan yang tidak dapat dipisahkan dari pendidikan lainnya. Melalui pendidikan jasmani aspek-aspek yang ada pada diri siswa akan dikembangkan secara optimal untuk mendukung pencapaian tujuan pendidikan secara keseluruhan. Tujuan pendidikan jasmani menurut Suherman (2000: 23) dapat diklasifikasikan ke dalam empat kategori yaitu: (1) perkembangan fisik; (2) perkembangan gerak; (3) perkembangan mental; dan (4) perkembangan sosial. Dengan adanya tujuan pendidikan jasmani diharapkan semua kalangan dalam pendidikan menyadari betapa pentingnya pendidikan jasmani di sekolah. Karena melalui aktivitas fisik seorang anak dapat menyalurkan kreasi dan keaktifannya dalam hal positif di bawah bimbingan dan arahan para guru. Untuk mencapai tujuan pendidikan secara keseluruhan maka pendidikan jasmani pun harus ditingkatkan dengan memaksimalkan kemampuan yang telah ada.

Pendidikan jasmani merupakan pendidikan yang diajarkan beberapa macam cabang olahraga menurut jenjang pendidikannya. Hal ini artinya, materi pendidikan jasmani mulai dari tingkat sekolah dasar sampai dengan tingkat sekolah di atasnya (SMP dan SMA/SMK) berbeda-beda. Depdiknas (2007: 3-4) menyatakan ruang lingkup matapelajaran pendidikan jasmani sekolah dasar meliputi aspek-aspek: permainan dan olahraga, aktivitas pengembangan, aktivitas senam, aktivitas ritmik, aktivitas air, pendidikan luar kelas dan kesehatan. Dalam usaha meningkatkan minat siswa dalam pendidikan jasmani seorang guru harus memahami karakteristik dan pola pikir siswa. Setelah mengetahui pola pikir anak sekolah dasar, sekarang instansi-instansi pendidikan gencar akan program pengembangan aktivitas anak di sekolah masing-masing, yang melibatkan para orang tua, guru, dan lingkungan sosial.

Dengan melibatkan banyak pihak diharapkan akan tercapainya tujuan pendidikan secara optimal, tapi kenyataannya selama ini banyak pihak yang terkait dalam pendidikan kurang memaksimalkan tujuan pendidikan, terutama pendidikan jasmani karena para guru masih bersifat konvensional, yaitu guru sebagai pusat dalam pembelajaran. Hal ini terlihat pada fenomena yang dialami oleh guru pendidikan jasmani saat mengajar Senam Kesegaran Jasmani yang biasa disingkat dengan SKJ. Sedangkan SKJ itu sendiri adalah salah satu aktivitas senam yang sebagian besar di setiap sekolah dasar harus dapat menerapkannya sebagai senam rutin yang diselenggarakan setiap hari Jumat. SKJ adalah senam baku yang dibuat tiap empat tahun sekali oleh ASKI (Asosiasi Kebugaran Indonesia) dibawah naungan Deputi Bidang Pemberdayaan Olahraga Kementerian Negara Pemuda dan Olahraga. Sehingga diadakan pelatihan untuk guru-guru pendidikan jasmani dan para instruktur senam seluruh Indonesia. Bagi peserta pelatihan SKJ diharapkan dapat menularkan ilmu yang didapatnya, untuk guru-guru penjasorkes dapat mengajarkan hasil pelatihan SKJ tersebut kepada siswanya.

Tetapi dengan melihat kenyataan yang ada guru penjasorkes mengajarkan kepada anak didiknya hanya sebatas tahu dan hal terpenting bagi guru adalah semua siswanya dapat dengan cepat hafal gerakan SKJ, walaupun siswa melakukan gerakan SKJ secara asal-asalan yang jauh dari gerakan baku dan benar. Oleh karena itu peneliti melihat adanya ketidak berhasilan guru pendidikan 
jasmani dalam mengajarkan SKJ, yaitu tidak sesuai dengan tujuan pendidikan jasmani, dan tidak tercapainya penyampaian gerakan yang benar dan utuh kepada siswa. Sedangkan SKJ diciptakan dengan tujuan untuk meningkatkan kesegaran jasmani, apabila dilakukan dengan asal-asalan maka pencapaian kesegaran jasmani jauh dari maksimal. Kesegaran jasmani menurut Dinata (2003: 16) yaitu kesegaran jasmani adalah kemampuan seseorang duntuk melaksanakan tugas sehari-hari tanpa mengalami kelelahan yang berarti dan masih memilki cadangan tenaga untuk melaksanakan kegiatan itu. Untuk anak sekolah dasar yang masih gemar bermain akan membutuhkan kesegaran jasmani yang prima setiap harinya, karena siswa akan terus aktif dalam aktivitas di sekolah, di rumah, serta lingkungan sekitar.

SKJ 2012 diciptakan guna menyempurnakan SKJ sebelumnya yaitu SKJ 2008. Sehingga dalam pelaksanaan pembelajaran pendidikan jasmani yang kurang maksimal akan berdampak pula pada hasil belajar siswa tentang aktivitas ritmik yaitu SKJ, melihat banyaknya siswa tiap sekolah dasar yang berbeda-beda akan mengakibatkan kurang efektifnya pembelajaran. Guru pendidikan jasmani yang kurang mengembangkan media pembelajaran akan berdampak pula terhadap minat belajar siswa, sehingga proses pembelajaran pendidikan jasmani khususnya materi SKJ di sekolah dasar dilaksanakan dalam situasi yang monoton. Sedangkan menurut Sudjana dan Rivai (2007: 64) yaitu cara-cara menggunakan media dan menciptakan lingkungan (settings) dimana media dipergunakan untuk mempengaruhi, memodifikasi, memanipulasi kondisi penyajian materi instruksional dan respon penerima informasi, yaitu siswa.

Hasil pengamatan dan observasi di SD Negeri 1 Panggung Barat pada matapelajaran Pendidikan Jasamani Olahraga dan Kesehatan (Penjasorkes) tentang SKJ 2012, yaitu pembelajaran senam di kelas V tersebut belum memenuhi standar gerakan baku dalam SKJ 2012, karena guru penjasorkes sekolah tersebut belum pernah mengikuti pelatihan SKJ 2012. Dengan melihat latar belakang sekolah yaitu sebagai sekolah dasar yang unggulan di Kecamatan Barat, akan tetapi siswanya belum melakukan gerakan SKJ 2012 dengan benar. Dengan memehatikan kondisi siswa, penerapan video SKJ 2012 saat pembelajaran SKJ 2012 diharapkan dapat meningkatkan gerakan SKJ 2012 ke arah yang benar dan baku.

Dari observasi awal mengenai pelaksanaan gerakan SKJ 2012 dapat dilihat secara keseluruhan bahwa di kelas V tersebut hanya ada dua orang yang hafal dan gerakannya mendekati benar saat melakukan gerak SKJ 2012. Dalam persentasenya adalah $12,9 \%$ di kelas $\mathrm{V}$ tersebut dari total keseluruhan 30 siswa. Sehingga peneliti dan guru Penjas berkolaborasi dalam penelitian ini untuk meningkatkan gerakan SKJ 2012 sesuai gerakan baku dan benar. Burns menyatakan bahwa yang mendukung penelitian kolaboratif, mengingatkan bahwa pandangan individualistik ini bertentangan dengan tujuan asli penelitian tindakan, yang diharapkan menghasilkan perubahan dalam situasi sosial sebagai hasil dari pemecahan masalah dan kolaborasi kelompok. Sedangkan kolaborasi yang dimaksud di sini adalah sudut pandang setiap orang akan dianggap memberikan andil pada pemahaman, tidak ada sudut pandang seseorang yang akan dipakai sebagai pemahaman tuntas dan mumpuni dibandingkan dengan sudut-sudut pandang lainnya (Madya, 2009: 51). 
Guru adalah sumber belajar yang dibantu oleh sumber lainnya, yaitu media pengajaran. Dengan tetap mendampingi siswa saat pembelajaran SKJ 2012 guru Penjas dan peneliti menerapkan video SKJ 2012 yang bertujuan agar siswa dapat mengetahui gerakan yang baku dan benar. Sedangkan media video itu sendiri adalah alat untuk menampilkan informasi secara audio visual khususnya gambar gerak yang dipelajari. Penekanan utama dalam pengajaran audio-visual adalah pada nilai belajar yang diperoleh melalui pengalaman konkret, tidak hanya didasarkan atas kata-kata belaka. Menurut Sudjana (2007: 58) pengajaran audiovisual bukan metode mengajar. Materi audio-visual hanya dapat berarti bila dipergunakan sebagai bagian dari proses pengajaran. Peralatan audio-visual tidak harus digolongkan sebagai pengalaman belajar yang diperoleh dari penginderaan pandang dan dengar, tetapi sebagai alat teknologis yang bisa memperkaya serta memberikan pengalaman konkret kepada siswa.

Berdasarkan observasi yang dilakukan terdapat permasalahan yang dialami oleh guru Penjas dan siswa dalam penyampaian materi Pendidikan Jasmani Olahraga dan Kesehatan khususnya saat pembelajaran SKJ 2012, maka peneliti menggali dengan Penelitian Tindakan Kelas pada siswa kelas V SD Negeri 1 Panggung Barat Magetan.

\section{B. METODE PENELITIAN}

Penelitian ini dilaksanakan di SD Negeri 1 Panggung Barat Magetan. Peneliti memilih sekolah tersebut karena berdasarkan survei, masih kurangnya pembelajaran SKJ 2012. Dimana belum memanfaatkan media video sebagai alat pembelajaran. Selain itu SD Negeri 1 Panggung merupakan sekolah unggulan di Kecamatan Barat Magetan. Penelitian dilakukan secara kolaborasi dengan guru Penjas SD Negeri 1 Panggung Barat Magetan, materi SKJ 2012, saat jam pelajaran Penjas yaitu pukul 07.00 sampai dengan pukul 08.10 WIB. Subjek penelitian ini adalah keseluruhan siswa kelas V SD Negeri 1 Panggung Barat Magetan Tahun Pelajaran 2012/2013 yang berjumlah 30 siswa. Dengan rincian 16 siswa putra dan 14 siswa putri.

Sumber data yang dipergunakan dalam Penelitian Tindakan Kelas (PTK) ini adalah: (1) siswa, untuk mendapatkan data tentang tes SKJ 2012 dengan penerapan video SKJ 2012 pada siswa kelas V SD Negeri 1 Panggung Barat Magetan; dan (2) guru sebagai kolaborator, untuk melihat tingkat keberhasilan penerapan video SKJ 2012 dalam proses pembelajran SKJ 2012 pada siswa kelas V SD Negeri 1 Panggung Barat Magetan.

Teknik pengumpulan data dalam Penelitian Tindakan Kelas (PTK) ini adalah tes unjuk kerja. Tes unjuk kerja dipergunakan untuk mendapatkan data tentang hasil gerakan SKJ 2012 yang dilakukan oleh siswa. Data yang dikumpulkan dalam penelitian ini meliputi informasi tentang keadaan siswa dilihat dari aspek kualitatif, yakni hasil penilaian gerakan SKJ 2012 yang sesuai dengan formulir penilaian yang baku, dilakukan oleh siswa kelas V SD Negeri 1 Panggung Barat Magetan. Hasil pengamatan dan catatan pembelajaran selama penelitian berlangsung dan tindakan per Siklus akan menjadi data pelengkap. Teknik analisis data yang digunakan dalam Penelitian Tindakan Kelas ini adalah deskriptif kaulitatif. Menurut Miles dan Huberman menyatakan bahwa:

Analisis data kualitatif tentang mempergunakan kata-kata yang selalu disusun dalam sebuah teks yang diperluas atau dideskripsikan. Pada saat 
memberikan makna paada data yang dikumpulkan, maka penulis menganalisis dan mengintrepetasikan data. Karena penelitian bersifat kualitatif, maka analisis data berlangsung mulai dari awal penelitian sampai penelitian akhir yang dituangkan dalam laporan penelitian yang dilakukan secara simultan dan terus menerus. Selanjutnya interpretasi atau penafsiran data dilakukan dengan mengacu pada rujukan teoritisyang berhubungan atau berkaitan dengan permasalahan penelitian (Iskandar, 2009: 74).

Sedangkan menurut Sugiyono analisis data kualitatif adalah proses mencari dan menyusun secara sistematis data yang diperoleh dari hasil pengamatan (observasi), wawancara, catatan lapangan, dan studi dokumentasi, dengan cara mengorganisasikan data ke sintesis, menyusun ke dalam pola, memilih mana yang penting dan mana yang akan dipelajari, dan membuat kesimpulan sehingga mudah dipahami oleh diri sendiri maupun orang lain (Iskandar, 2009: 74). Dapat disimpulkan bahwa analisis data Penelitian Tindakan Kelas merupakan proses memilih, memilah, membuang, menggolongkan, serta menyusun ke dalam kategorisasi, mengklarifikasi data untuk menjawab pertanyaan, tema apa yang ditemukan pada data, seberapa jauh data dapat mendukung tema atau tujuan PTK. Dalam pelaksanaan PTK ini memakai data kualitatif yang berupa hasil tes SKJ 2012 maupun pengamatan yang dilakukan peneliti dan guru Penjas.

Menurut Iskandar (2009: 130) yang menyatakan bahwa data yang dikumpulkan pada setiap kegiatan observasi dari pelaksanaan siklus PTK dianalisis secara deskriptif dengan menggunakan persentase untuk melihat kecenderungan yang terjadi dalam kegiatan pembelajaran. Tujuan yang ingin dicapai dalam penelitian ini adalah meningkatkan gerakan SKJ 2012 dengan penerapan video SKJ 2012 pada siswa kelas V SD Negeri 1 Panggung Barat Magetan. Pelaksanaan Penelitian Tindakan Kelas (PTK) ini melalui tiga tahapan siklus, ketiga tahapan tersebut terdiri dari (1) perencanaan tindakan, (2) pengamatan tindakan, dan (3) refleksi tindakan sebagai berikut:

\section{Rancangan Siklus I}

1. Perencanaan Tindakan

Pada tahap ini peneliti dan guru kelas menyusun sekenario pembelajaran yang terdiri dari:

a. Peneliti dan kolaborator melakukan analisis kurikulum untuk mengetahui kompetensi dasar yang akan disampaikan kepada siswa dalam pembelajaran penjasorkes;

b. Membuat rencana pembelajaran dengan mengacu pada tindakan (treatment) yang diterapkan dalam PTK, yaitu pembelajaran gerakan pemanasan SKJ 2012;

c. Menyusun instrumen yang digunakan dalam siklus PTK, yaitu penilaian SKJ 2012;

d. Menyiapkan media yang diperlukan untuk membantu pengajaran.

\section{Pelaksanaan Tindakan}


Deskripsi tindakan yang akan dilakukan, skenario kerja tindakan perbaikan yang akan dikerjakan dan prosedur tindakan yang akan diterapkan adalah:

a. Penerapan media video SKJ 2012 di kelas dengan menggunakan tampilan LCD Proyektor atau Digital Proyektor;

b. Praktik di lapangan sesuai rencana pembelajaran yang telah dibuat tentang SKJ 2012;

c. Dalam rencana pelaksanaan pembelajran dilakukan secara bertahap yaitu dimulai pembelajaran gerakan Pemanasan, Inti, dan Pendinginan SKJ 2012. Dalam pembelajaran ini peneliti dan guru Penjas ikut serta dalam pelaksanaan untuk membenarkan gerakan SKJ 2012 yang dipraktikkan siswa.

\section{Pengamatan/Observasi Tindakan}

Pengamatan dilakukan terhadap: (1) situasi belajar saat di kelas penerapan video SKJ 2012; dan (2) kemampuan siswa saat pelaksanaan gerakan SKJ 2012. Adapun instrumen yang digunakan peneliti dalam pengamatan adalah penilaian SKJ 2012.

\section{Refleksi terhadap Tindakan}

Refleksi merupakan analisis, sintesis, dan penilaian terhadap hasil perencanaan, pelaksanaan, dan pengamatan yang dilakukan PTK jika terdapat masalah dari proses refleksi maka dilakukan proses pengkaji ulang melalui siklus berikut yang meliputi perencanaan, pelaksanaan, pengamatan sehingga permasalahan dapat teratasi. Tahapan ini dimaksud untuk uraian tentang prosedur analisis terhadap hasil penelitian dan refleksi berkaitan dengan proses dan dampak tindakan perbaikan yang dilaksanakan pada siklus kedua.

\section{Rancangan Siklus II dan III}

Pada rancangan siklus II dan siklus III tindakan dikaitkan dengan hasil yang telah dicapai pada tingkatan siklus I sebagai upaya perbaikan dari siklus tersebut dengan materi pembelajaran sesuai dengan silabus matapelajaran pendidikan jasmani olahraga dan kesehatan. Demikian pula dengan siklus III merupakan rancangan perbaikan dari siklus II dan seterusnya, termasuk perwujudan tahap pelaksanaan, observasi, dan interprestasi, serta analisis dan refleksi yang juga mengacu pada siklus sebelumnya. Sehingga dapat ditarik kesimpulan atas pelaksanaan pembelajaran berdasarkan tindakan (treatment) dalam penerapan media video SKJ 2012 untuk meningkatkan gerakan SKJ 2012.

\section{HASIL PENELITIAN}

\section{Siklus I}

Siklus I pada tahap perencanaan, kegiatan perencanaan tindakan I dilaksanakan pada hari Jumat 1 Maret 2013 di SD Negeri I Panggung Barat Magetan. Peneliti dan guru Penjas mendiskusikan rancangan tindakan yang akan dilakukan dalam proses penelitian ini sebelumnya. Kemudian disepakati bahwa pelaksanaan tindakan pada siklus I akan dilaksanakan selama tiga kali pertemuan, sesuai dengan jadwal olahraga kelas $\mathrm{V}$ dan menambah hari lain di luar jadwal olahraga, atas seijin kepala sekolah SD Negeri 1 Panggung Barat Magetan. Guru Penjas bersama peneliti mengukur tingkat keberhasilan pembelajaran SKJ 2012 pada siklus I ini dengan cara mengamati secara teliti untuk dapat mengetahui 
pencapaian target $30 \%$ di siklus I yaitu dengan target 9 siswa yang sudah dapat dengan benar menghafal gerakan pemanasan SKJ 2012 sesuai gerakan baku. Berdasarkan indikator target pencapaian, peneliti dan guru Penjas merencanakan tindakan I dengan kegiatan sebagai berikut:

a. Peneliti dan guru Penjas melakukan analisis kurikulum untuk mengetahui kompetensi dasar yang akan disampaikan kepada siswa dalam pembelajaran penjasorkes;

b. Membuat Rencana Pelaksanaan Pembelajaran (RPP) dengan mengacu pada tindakan (treatment) yang diterapkan dalam PTK, yaitu pembelajaran gerakan pemanasan SKJ 2012;

c. Menyusun instrumen yang digunakan dalam siklus PTK, yaitu penilaian SKJ 2012 yang dilakukan saat Prasiklus dan Pascasiklus SKJ 2012 untuk mengetahui seberapa besar peningkatannya;

d. Menyiapkan media yang diperlukan untuk membantu pengajaran.

Dalam siklus I terdapat tiga kali pertemuan pembelajaran SKJ 2012 yang dilakukan oleh peneliti dan guru Penjas. Analisis data yang dikumpulkan pada siklus I yaitu dalam rangkuman pembelajaran, sebagai berikut:

Pada pengajaran dan pertemuan pertama hari Jumat 8 Maret 2013, siswa masih belum bisa konsentrasi dengan pengajaran yang diberikan, tapi saat penggunaan media tampak menarik perhatian siswa dan melibatkan sebagian besar indra mereka. Penggunaan media saat di ruang kelas siswa dapat dengan tenang mengamati gerakan pemanasan SKJ 2012. Kemudian siswa berpindah tempat ke halaman untuk praktik langsung gerakan yang benar dalam SKJ 2012 saat dipertontonkan di ruang kelas sebelumnya. Dengan cara demonstrasi kepada siswa, peneliti dan guru Penjas saling membantu mengamati dan mengawasi siswa yang belum bisa dengan gerakan benar dalam SKJ 2012. Pengajaran SKJ diawali dari gerakan 1 \& 2 dalam Pemanasan SKJ 2012. Pada pengajaran pertama ini sebagian kecil sudah ada yang dapat melakukan gerakan dengan benar tetapi masih banyak yang belum bisa dengan benar, sehingga masih perlu banyak latihan untuk siswa sendiri dan peneliti dalam memotivasi siswa untuk dapat melakukan gerakan dengan benar SKJ 2012.

Pada pengajaran dan pertemuan kedua dilaksanakan pada hari Jumat 15 Maret 2013 bertempat di SD 1 Panggung Barat Magetan. Suasana sore yang sepi membuat siswa lebih nyaman dan dapat fokus dengan pembelajaran SKJ 2012, baik saat penerapan video SKJ 2012 di kelas maupun praktik di halaman sekolah. Sehingga peneliti mulai mendapat simpati dari semua siswa kelas V, yaitu semua siswa mau melakukan yang peneliti dan guru Penjas suruh demi keberhasilan menghafal gerakan SKJ 2012 dan gerakan tersebut menjadi benar. Cara tersebut adalah saat peneliti berada di kelas dengan menampilkan video SKJ 2012 dengan menggunakan Laptop dan tampilan LCD, setelah siswa melihat cuplikan gerakan pemanasan mereka dapat membayangkan gerakan tersebut dengan cara menutup mata sambil mendengarkan instruksi dari peneliti. Pada pertemuan sore kali ini peneliti menambah materi dalam gerakan Pemanasan SKJ 2012 yaitu gerakan 3, 4, dan 5. Kemudian siswa berpindah ke halaman sekolah untuk mempraktikkan gerakan yang dilihat dan dibayangkan tadi, dengan tidak melupakan gerakan yang 
sudah dipelajari saat pertemuan pertama. Peneliti dan guru Penjas melakukan pendekatan secara individu, agar lebih efektif dan intensif langsung mengenai sasaran yaitu siswa. Walaupun kemampun peneliti dan guru Penjas terbatas untuk mengawasi semua siswa yang berjumlah 30 siswa.

Pada pengajaran dan pertemuan ketiga pada hari Jumat 22 Maret 2013 yaitu sesuai jadwal olahraga kelas $\mathrm{V}$, dan ini adalah pertemuan terakhir di siklus I. Proses pembelajaran dapat dikatakan relatif baik dari segi interaksi antara peneliti, guru Penjas, dan siswa dalam suasana yang selalu menyenangkan. Siswa sudah merasakan senang dalam pembelajaran SKJ 2012 menggunakan media video dengan tampilan Laptop dan LCD. Sehingga siswa dengan mudah memahami gerakan yang benar. Siswa merasa bersemangat dalam pembelajaran penjasorkes cabang senam khususnya SKJ 2012, terlihat siswa yang sering meminta belajar SKJ 2012 karena mereka sudah termotivasi untuk dapat melakukan gerakan yang benar dan ingin cepat hafal. Hal itu membuat peneliti mempunyai percaya diri yang kuat untuk terus mengajarkan SKJ 2012 kepada siswa kelas V. Dalam pertemuan kali ini peneliti menambah gerakan yaitu gerakan Pemanasan terakhir adalah gerakan 6. Dengan mengulang-ulang gerakan yang sudah dipelajari sebelumnya dan menambah sedikit demi sedikit gerakan pemanasan yang akhirnya dapat tercapai sesuai target indikator capaian yaitu 9 siswa sudah berhasil dalam siklus I ini. Untuk siswa yang masih ketinggalan akan peneliti dekati secara individu saat pembelajran berlangsung, dengan bantuan dari guru Penjas yang mengawasi siswa lainnya.

Pengamatan dilakukan terhadap: (1) situasi belajar saat di kelas penerapan video SKJ 2012; dan (2) kemampuan siswa saat pelaksanaan gerakan SKJ 2012. Adapun instrumen yang digunakan peneliti dalam pengamatan adalah penilaian SKJ 2012. Hasil pengamatan siswa dalam proses pembelajaran pada siklus I sudah dapat dikatakan berhasil dengan pemenuhan indikator target capaian pada siklus I yaitu 30\%. Dimana target pencapaian 30\% dari 30 siswa adalah 9 siswa. Pada siklus I ini siswa-siswa yang sudah berhasil dengan sepenuhnya menguasai gerakan pemanasan SKJ 2012 sesuai dengan gerakan baku dan sudah hafal benar Hasil evaluasi keseluruhan pertemuan dari siklus I, bahwa kebanyakan murid masih kurang dalam hal konsentrasi dan minat belajar SKJ 2012. Walaupun sesuai dengan indikator target pencapaian pada siklus I terpenuhi dengan jumlah 9 siswa seperti yang ditargetkan peneliti sebelumnya untuk pembelajaran gerakan Pemanasan SKJ 2012 yang baku dan hafal dengan benar.

\section{Refleksi terhadap Tindakan}

Adapun keberhasilan dan kegagalan yang terjadi pada siklus I adalah:

a. Target pada siklus I yaitu 30\% dari 30 siswa adalah 9 siswa, sudah terpenuhi tetapi masih banyak siswa yang belum bisa menguasai gerakan pemanasan pada SKJ 2012;

b. Saat penerapan video SKJ 2012 di ruang kelas para siswa masih banyak yang asyik sendiri tanpa memperhatikan tampilan video;

c. Kurangnya konsentrasi siswa saat pembelajaran SKJ 2012 baik di ruang kelas maupun di halaman sekolah. Karena siswa masih belum terlalu berminat, walaupun tidak semua siswa kurang berkonsentrasi. Terutama siswa laki-laki yang masih asyik dengan teman-temannya dan ramai sendiri; 
d. Masih terdapat siswa yang belum patuh terhadap peneliti dan guru Penjas sehingga masih suka bermain sendiri saat pembelajaran SKJ 2012 di halaman sekolah.

\section{Siklus II}

Untuk memperbaiki kelemahan dan mempertahankan keberhasilan yang telah dicapai pada siklus I, maka pada pelaksanaan di siklus II dibuat perencanaan sebagai berikut:

a. Memberikan motivasi kepada siswa yang masih mengalami kesulitan dalam belajar gerakan SKJ 2012;

b. Lebih intensif dalam memberikan bimbingan dan arahan kepada siswa yang masih tertinggal dari teman-teman lainnya;

c. Memberikan pengakuan atau penghargaan (reward) berupa acungan ibu jari maupun dengan kata-kata: bagus, sip, benar; kepada siswa yang sudah benar dalam gerakan SKJ 2012 dan memberikan semangat untuk bisa pada siswa yang masih belum bisa;

d. Pembagian kelompok untuk memudahkan menghafal nama-nama siswa dan nomer urut siswa. Sehingga siswa berbaris sesuai dengan nomor urutnya, seperti saat pengambilan nilai tes awal SKJ 2012. Yaitu terdapat 6 kelompok dengan jumlah enam siswa setiap kelompok kecuali kelompok 5 yang berjumlah empat siswa dan kelompok 6 yang berjumlah tiga siswa.

Siklus II untuk melanjutkan action pada siklus I yaitu pembelajaran SKJ 2012 dilanjutkan mempelajari gerakan inti yang terdapat lima gerakan inti didalamnya. Gerakan Pemanasan SKJ 2012 tetap diulang terus agar lebih mantap dan siswa yang bisa lebih banyak, sehingga tingkat otomatisasi gerak menjadi lancar dengan konsep pada siklus II ini adalah menambah materi dari gerakan peralihan dan gerakan inti.

Perencanaan pada hari Sabtu 23 Maret 2013 di SD Negeri I Panggung Barat Magetan, peneliti dan guru Penjas melaksanakan kegiatan belajar mengajar rutin tiap minggunya yaitu penjasorkes untuk kelas V. Sebelumnya peneliti dan guru Penjas sudah berdiskusi untuk mengambil langkah selanjutnya dalam siklus II ini, karena peneliti sudah menyampaikan kendala dan keberhasilan pada siklus I kemarin. Sehingga dalam kesempatan kali ini, peneliti dan guru Penjas lebih giat lagi dalam memperhatikan siswa saat pembelajaran SKJ 2012 baik itu saat penerapan video maupun saat praktik di halaman sekolah.

Untuk mengatasi berbagai kekurangan yang ada, akhirnya peneliti dan guru Penjas mengambil keputusan sebagai berikut:

a. Peneliti menambah materi pembelajaran SKJ 2012 dari siklus I mempelajari gerakan Pemanasan untuk siklus II ini ditambah ke gerakan inti SKJ 2012;

b. Dengan cara pembelajaran dan konsep yang sama seperti siklus I, tetapi peneliti dan guru Penjas lebih memperhatikan siswa dan memotivasi siswa untuk bisa menghafalkan gerakan SKJ 2012 dengan baku dan benar;

c. Peneliti selalu berpindah-pindah saat mengajar dengan mendekati siswa yang kurang bersemangat, guru sesekali berada di depan siswa dan sesekali berada di belakang maupun di tengah saat pembelajaran tersebut;

d. Peneliti dalam memberikan penjelasan harus dengan suara yang lantang atau keras sehingga semua anak dapat mendengar intruksi dengan jelas; 
e. Peneliti memberikan penjelasan yang jelas dan benar saat di ruang kelas maupun saat di halaman, sehingga siswa tidak merasa asing atau canggung lagi;

f. Peneliti dan guru Penjas lebih perhatian kepada siswa yang masih belum bisa melakukan gerakan demi gerakan secara benar, sehingga peneliti dan kolaborator lebih bersifat pendekatan individual kepada siswa saat kegiatan belajar mengajar berlangsung.

Tahap perencanaan siklus II berdasarkan replaning siklus I meliputi kegiatan sebagai berikut:

a. Peneliti bersama guru Penjas merancang skenario pembelajaran SKJ 2012 yaitu gerakan Inti dengan mengulang gerakan pemanasan SKJ 2012 terlebih dahulu yang dipelajari pada siklus I, dengan langkah-langkah:

1) Peneliti menjelaskan mengenai materi yang akan diajarkan pada hari itu, siswa menyimak. Dengan kondisi kelas yang tenang sehingga siswa dapat dengan fokus melihat dan mengamati gerakan-gerakan yang benar pada video SKJ 2012 yang ditampikan. Peneliti dengan menerangkan dan memperjelas lagi di depan kelas yaitu gerakan per gerakan saat inti SKJ 2012;

2) Peneliti memberikan contoh pembelajaran SKJ 2012 saat berada di halaman untuk praktik gerakan inti SKJ 2012. Siswa berbaris menurut absen dibagi menjadi 4 sab, sehingga peneliti dan guru Penjas dapat dengan mudah mengawasi siswa dan dapat hafal siswa yang sudah bisa dan siswa yang masih perlu bimbingan lebih atau masih kurang;

3) Peneliti dan siswa melakukan refleksi terhadap proses belajar mengajar yang telah dilakukan saat penutupan kegiatan pembelaajaran, yaitu dengan cara mengevaluasi dan peneliti mengadakan umpan balik untuk siswa tentang pembelajran yang dilakukan khususnya gerakan per gerakan dalam SKJ 2012 yang dipelajari sekarang;

b. Peneliti dan guru Penjas menyusun Rencana Pelaksanaan Pembelajaran (RPP) untuk materi yang berkaitan dengan pembelajran SKJ 2012, pada siklus II ini pembelajaran SKJ 2012 difokuskan pada gerakan inti yang terbagi dalam lima gerakan;

c. Guru Penjas bersama peneliti menyiapkan media yang diperlukan dalam pembelajaran SKJ 2012 saat berada di kelas yaitu Laptop dan LCD;

d. Peneliti dan guru Penjas menyusun instrumen penelitian, yakni berupa tes dan nontes. Instrumen tes dinilai dari pelaksanaan SKJ 2012 dari pemanasan yang dipelajari pada siklus I sampai gerakan inti yang baru dipelajari, siswa melakukan secara serentak dengan baris sesuai nomor urut dibagi menjadi 4 bersab. Sedangkan instrumen non tes dinilai berdasarkan observasi yang dilakukan oleh peneliti dengan mengamati keaktifan dan sikap siswa selama kegiatan pembelajaran berlangsung.

Pelaksanaan tindakan II ini direncanakan berlangsung selama tiga kali pertemuan, yakni pada hari Jumat 29 Maret 2013, hari Jumat 5 April 2013, dan hari Jumat 12 April 2013 di halaman SD Negeri I Panggung Barat Magetan. Masing-masing pertemuan dilaksanakan selama 2 x 35 menit, pada hari Jumat dilaksanakan sesuai dengan jadwal rutin olahraga kelas $\mathrm{V}$ yaitu dimulai pukul 07.00 WIB. 
Sesuai dengan skenario pembelajaran pada siklus II ini pembelajaran dilakukan oleh peneliti. Peneliti sekaligus melakukan observasi terhadap proses pembelajaran selama berlangsungnya kegiatan belajar mengajar dengan bantuan guru Penjas. Materi pelaksanaan tindakan II pada pertemuan pertama di siklus II (Jumat 29 Maret 2013) ini adalah pembelajaran SKJ 2012 gerakan peralihan dan gerakan inti $1 \& 2$, sebelum masuk ke materi gerakan Inti siswa disuruh untuk melakukan gerakan Pemanasan terlebih dahulu, agar lebih hafal. Urutan pelaksanaan tindakan tersebut adalah:

a. Peneliti menerapkan video SKJ 2012 dari gerakan pemanasan sampai gerakan inti, siswa menyimak dengan seksama;

b. Peneliti menjelaskan materi bersamaan siswa yang sedang menyimak tampilan video SKJ 2012, dengan gambar gerak secara audio-visual dan penjelasan langsung diharapkan siswa dapat lebih paham dan mengerti tentang gerakan yang benar;

c. Peneliti memberi contoh gerakan atau demonstrasi gerakan saat semua siswa berada di halaman sekolah, dengan barisan sesuai absen. Siswa mengulang gerakan pemanasan SKJ 2012 terlebih dahulu sebelum masuk ke gerakn Inti SKJ 2012. Setelah itu siswa diberikan contoh Gerakan Peralihan (GP), kemudian atas instruksi peneliti siswa mengikuti dengan seksama. Guru Penjas ikut membenarkan gerakan siswa yang masih salah dan membantu menjelaskan gerakan demi gerakan kepada siswa. Setelah dirasa cukup pemberian materi GP kemudian pembelajaran gerakan Inti satu. Dibantu oleh guru Penjas siswa yang masih kesulitan dalam mengaplikasikan gerakan benar, dilakukan pendekatan individu atau satu persatu;

d. Peneliti selalu berpindah-pindah tempat untuk dapat mengawasi dan melihat siswa saat pembelajaran;

e. Peneliti sesekali memakai irama atau musik SKJ 2012 untuk penam,bah semangat siswa, tetapi hal tersebut dilakukan peneliti setelah lumayan banyak siswa menguasai gerakan Inti satu barulah memakai musik yang sesungguhnya;

f. Siswa melakukan gerakan demi gerakan dengan semangat karena peneliti tidak melatih mereka tetapi memberikan hal baru dalam pembelajaran dengan konsep penerapan video SKJ 2012 dan belajar gerakan secara langsung di halaman sekolah. Karena peneliti selalu menjaga komunikasi dengan siswa, terkadang siswa minta istirahat sebentar untuk minum dan pergi ke kamar kecil. Sehingga pembelajran tetap mengasyikkan walaupun siswa mempunyai tuntutan yang besar untuk dapat menguasai gerakan SKJ 2012 secar benar dan hafal betul gerakan demi gerakan;

g. Peneliti selalu menanyakan kepada siswa apakah ada yang merasa kesulitan saat pembelajaran SKJ 2012, terutama saat melakukan gerakan;

h. Peneliti memotivasi siswa agar mempunyai semangat dalam melakukan gerakan demi gerakan dengan benar.

Materi pada pelaksanaan tindakan II, pada pertemuan kedua (Jumat 5 April 2013). Urutan pelaksanaan tindakan tersebut adalah:

a. Peneliti menerapkan video SKJ 2012 dari gerakan pemanasan sampai gerakan Inti, siswa menyimak dengan seksama. Terkadang peneliti bertanya kepada siswa apakah ada yang tidak tahu tentang gerakan tersebut; 
b. Peneliti menjelaskan materi bersamaan dengan siswa sedang menyimak video yang ditampilkan, dengan tampilan gambar gerak dan penjelasan langsung diharapkan siswa dapat lebih paham dan mengerti dengan jelas gerakan benar itu. Siswa yang benar-benar menyimak terkadang tangannya ikut menirukan gerakan yang ditampilkan di video;

c. Peneliti memberi contoh gerakan atau demonstrasi saat semua siswa berada di halaman sekolah, dengan barisan sesuai absen. Siswa mengulang gerakan pemanasan SKJ 2012 terlebih dahulu sebelum masuk ke gerakan Inti SKJ 2012. Melanjutkan gerakan kemarin sekarang ditambah gerakan yaitu Inti 3 dan Inti 4, dimana kedia Inti ini adalah gerakan Inti yang paling sulit dari pada gerakan Inti yang lainnya. Karena memakai koordinasi gerak yang cukup rumit dan butuh tenaga yang lebih untuk melakukan gerakan tersebut;

d. Peneliti selalu berpindah-pindah tempat untuk dapat mengawasi dan melihat siswa saat pembelajaran. Karena masih banyak siswa yang belum dapat menguasai gerakan Inti $3 \& 4$, sehingga banyak diantaranya dari siswa yang mengeluh sulit untuk gerakan ini. Disinilah peran guru Penjas yang membantu peneliti yaitu dengan menumbuhkan semangat siswa dan membantu membenarkan gerakan siswa satu persatu tetapi dilakukan secara kolektif. Dan membantu mengatur siswa jika ada yang tidak mematuhi perintah peneliti;

e. Peneliti sesekali memakai irama atau musik SKJ 2012 sebagai penambah semangat siswa, tetapi hal tersebut dilakukan peneliti setelah lumayan banyak siswa menguasai gerakan Inti 3 barulah memakai musik yang sesungguhnya, kalau sudah dirasa cukup menguasai Inti 3 \& 4 barulah di 20 menit akhir pembelajaran, peneliti menginstruksikan kepada siswa untuk mengulang gerakan SKJ 2012 dari awal sampai gerakan terakhir yang dipelajari tadi memakai iringan musik. Sesekali peneliti berada di depan memberikan contoh kemudian siswa menirukan dengan maksimal;

f. Siswa melakukan gerakan demi gerakan dengan semangat karena peneliti tidak melatih mereka tetapi memberikan hal baru dalam pembelajaran dengan konsep penerapan video SKJ. Karena peneliti selalu menjaga komunikasi dengan siswa, terkadang siswa minta istirahat sebentar untuk minum dan pergi ke kamar kecil. Sehingga pembelajaran tetap mengasyikkan walaupun siswa mempunyai tuntutan yang besar untuk dapat menguasai gerakan SKJ 2012 secar benar dan hafal betul gerakan demi gerakan. Dalam tahap ini peneliti bertindak sebagai pemimpin jalannya kegiatan pembelajaran SKJ 2012 baik di ruang kelas maupun di halaman sekolah.

Materi pada pelaksanaan tindakan II, pada pertemuan ketiga (Jumat, 12 April 2013) dilaksanakan kegiatan belajar mengajar sesuai jadwal setiap hari jumat pagi dari pukul 7.00 WIB dengan durasi waktu selama 2 × 35 menit. Dalam pertemuan kali ini menambah materi yaitu mempelajari gerakan Inti 5 dalam SKJ 2012. Urutan pelaksanaan tindakan tersebut adalah:

a. Peneliti dengan menerapkan video SKJ 2012 dari gerakan pemanasan sampai gerakan Inti, siswa menyimak dengan seksama. Terkadang peneliti bertanya kepada siswa apakah ada yang tidak bisa melakukan gerakan tersebut. Setelah menampilkan video SKJ 2012 sesekali peneliti memperlihatkan video lucu- 
lucu kepada siswa seperti film kartun saat ini yaitu Upin dan Ipin, sehingga siswa tidak akan merasa bosan saat penerapan video di kelas;

b. Peneliti menjelaskan materi bersamaan dengan siswa sedang menyimak video yang ditampilkan, dengan tampilan gambar gerak dan penjelasan langsung diharapkan siswa dapat lebih paham dan jelas. Siswa yang benar-benar menyimak terkadang tangannya ikut menirukan gerakan yang ditampilkan di video. Dengan gaya celotehan anak-anak usia 10 tahun yang masih asyik bermain sendiri dan suka menjahili temannya, untuk memfokuskannya lagi peneliti terkadang memperlihatkan gambar-gambar mereka saat pembelajaran sebelumnya, sehingga mereka dapat mengetahui letak kesalahan gerakan masing-masing siswa. Sehingga siswa dapat saling mengoreksi diri sendiri dan teman-temannya;

c. Peneliti memberi contoh gerakan atau demonstrasi gerakan saat semua siswa berada di halaman sekolah, dengan barisan sesuai absen. Siswa mengulang gerakan pemanasan SKJ 2012 terlebih dahulu sebelum masuk ke gerakn Inti SKJ 2012. Melanjutkan gerakan kemarin sekarang ditambah gerakan yaitu Inti 5 yang merupakan gerakan Inti terakhir dalam SKJ 2012. Inti 5 ini adalah gerakan inti yang paling mudah dibandingkan gerakan Inti sebelumnya. Selalu peneliti dan guru Penjas mendekati siswa yang belum bisa menirukan gerakan secara benar, agar semua siswa dapat dengan benar melakukan SKJ 2012 sesuai gerakan baku. Dengan memakai iringan musik pembelajran diulangi dari gerakan Pemanasan sampai gerakan inti;

d. Peneliti selalu berpindah-pindah tempat untuk dapat mengawasi dan melihat siswa saat pembelajaran. Peneliti melihat antusias siswa untuk dapat melakukan gerakan dengan benar yaitu mereka tetap bersungguh-sungguh saat peneliti memberikan contoh. Guru Penjas pun merasa senang ternyata siswa-siswa selama ini mampu melakukan SKJ 2012 dengan benar walaupun belum semuanya gerakan SKJ 2012 diajarkan oleh peneliti;

e. Peneliti sesekali memakai irama atau musik SKJ 2012 untuk penambah semangat siswa, tetapi hal tersebut dilakukan peneliti setelah sudah banyak siswa menguasai gerakan Inti 5 barulah memakai musik yang sesungguhnya, kalau sudah dirasa cukup menguasai Inti 5 barulah di 15 menit akhir pembelajaran, peneliti menginstruksikan kepada siswa untuk mengulang gerakan SKJ 2012 dari awal sampai gerakan terakhir yang dipelajari tadi memakai iringan musik. Sesekali peneliti berada di depan memberikan contoh kemudian siswa menirukan dengan maksimal, karena siswa belum semuanya hafal.

Pengamatan dilakukan terhadap: (1) situasi belajar saat di kelas penerapan video SKJ 2012; dan (2) kemampuan siswa saat pelaksanaan gerakan SKJ 2012. Adapun instrumen yang digunakan peneliti dalam pengamatan adalah penilaian SKJ 2012. Hasil observasi aktifitas siswa dalam proses pembelajaran pada siklus II sudah dapat dikatakan berhasil dengan pemenuhan indikator target pencapaian pada siklus II yaitu 60\%. Target pencapaian pada siklus II ini dari 30 siswa adalah 19 siswa. Pada siklus II ini siswa-siswa yang sudah berhasil dengan sepenuhnya menguasai gerakan pemanasan SKJ 2012 dan gerakan Inti sesuai dengan gerakan baku dan sudah hafal benar. 
Hasil evaluasi keseluruhan pertemuan dari siklus II, bahwa murid-murid sudah memahami dan dapat melakukan SKJ 2012 dengan benar, seperti contoh gerakan di video SKJ 2012. Sehingga siswa dapat merasa bangga karena keberhasilannnya sendiri mempelajari SKJ 2012 tiap tahap, walaupun baru sampai gerakan Pemanasan dan gerakan Inti. Dan pada siklus II ini dengan target pencapaian $60 \%$ sudah terpenuhi dari 30 siswa yang sudah melakukan gerakan benar dan hafal berjumlah 19 siswa. Hasil pada siklus II ini membuat peneliti semakin termotivasi untuk dapat membuat semua siswa melakukan gerakan SKJ 2012 secara benar, sedangkan dari pihak siswa merasa lebih unggul dari kelas VI atas keberhasilan mereka mempelajari gerakan SKJ 2012 sampai tahap siklus II.

\section{Refleksi terhadap Tindakan}

Adapun keberhasilan dan kegagalan yang terjadi pada siklus II adalah:

a. Target pada siklus II yaitu 60\% dari 30 siswa adalah 19 siswa, sudah terpenuhi tetapi masih ada siswa yang belum bisa menguasai gerakan Inti SKJ 2012;

b. Saat penerapan video SKJ 2012 di ruang kelas konsentrasi siswa sudah mulai fokus, mereka sudah mampu menangkap gerakan per gerakan dalam SKJ 2012;

c. Siswa sudah mampu melakasakan instruksi peneliti dan guru Penjas dengan bersungguh-sungguh. Dengan melihat siswa yang semakin bersemangat membuat peneliti lebih perhatian kepada semua siswa, sehingga komunikasi diantara peneliti dan siswa sangat baik. Disamping itu untuk menjaga komunikasi agar lebih baik lagi, peneliti selalu memberikan apresiasi berupa pujian: bagus, keren, nice, dengan mengacungkan jempol. Sehingga siswa merasa diperhatikan, kemudian mereka melakukan pembelajaran dengan senang gembira. Peneliti selalu tersenyum kepada siswa yang masih belum benar gerakannya, agar siswa merasa diperhatikan;

d. Terdapat juga siswa yang masih kurang antusias terhadap pembelajaran SKJ 2012, karena merasa kurang percaya diri, jarang masuk saat pembelajaran SKJ 2012.

Untuk memperbaiki kelemahan dan mempertahankan keberhasilan yang telah dicapai pada siklus II, maka saat pelaksanaan di siklus III dibuat perencanaan sebagai berikut:

a. Dengan konsep yang masih sama dengan siklus-siklus sebelumnya yaitu tiga kali pertemuan. Dengan lebih memberikan motivasi kepada siswa yang masih tertinggal dengan temannya, dengan cara menjaga komunikasi diantara masing-masing siswa;

b. Saat penerapan video SKJ 2012 di kelas tidak hanya menampilkan video SKJ 2012 saja, tetapi terdapat selingan video lucu agar siswa merasa terhibur dan tetap menjaga antusias mereka saat pembelajaran berlangsung;

c. Memberikan pengakuan atau penghargaan (reward) serta pujian kepada siswa yang sudah benar dalam gerakan SKJ 2012. Tetap memberikan penghargaan berupa pujian kepada siswa yang selalu berusaha untuk mengejar ketertinggalan dengan teman;

d. Pembagian kelompok atau sab dalam barisan untuk memudahkan menghafal nama-nama siswa dan nomer urut siswa. Sehingga siswa baris sesuai nomer 
urutnya, seperti saat pengambilan nilai tes awal SKJ 2012. Yaitu terdapat 6 kelompok dengan jumlah enam siswa setiap kelompok kecuali kelompok 5 yang berjumlah empat siswa dan kelompok 6 yang berjumlah tiga siswa. Saat pembelajaran di halaman sekolah semua siswa berbaris untuk mendapat materi yang sama, tetapi di akhir pembelajaran yaitu 20 menit akhir pelajaran setiap kelompok tadi mempraktikkan SKJ 2012 yang diajarkan secara bergantian.

\section{Siklus III}

Guna melanjutkan action pada siklus II yaitu pembelajaran SKJ 2012 yaitu mempelajari gerakan pendinginan dan mengulang-ulang gerakan SKJ 2012 dari awal sampai akhir, yakni pemanasan, inti, dan pendinginan secara keseluruhan. Pada tahap perencanaan, hari Senin 15 April 2013 di SD Negeri I Panggung Barat Magetan, peneliti dan guru Penjas melaksanakan kegiatan belajar mengajar rutin tiap minggunya yaitu penjasorkes untuk kelas V pada pukul 07.00 WIB. Hasil diskusi dengan guru Penjas yaitu peneliti telah menyampaikan keberhasilan dan kekurangannya saat siklus II sebelumnya, dimana siklus III ini merupakan action yang terakhir dalam penelitian ini. Sehingga peneliti berusaha keras untuk dapat mencapai target dalam siklus III ini yang sudah di konsep dalam pencapaian target yaitu $80 \%$ dari 30 siswa, sehingga yang harus berhasil adalah 25 siswa.

Untuk mengatasi berbagai kekurangan yang ada, akhirnya peneliti dan guru Penjas mengambil keputusan sebagai berikut:

a. Peneliti menambah materi pembelajaran SKJ 2012 dari siklus II mempelajari gerakan peralihan dan inti $1,2,3,4, \& 5$, dalam siklus ini dilanjut mempelajari gerakan Pendinginan. Dengan mengulang-ulang gerakan diharapkan siswa akan lebih hafal dan dapat melakukan dengan benar. Dilakukan sesekali dengan iringin musik SKJ 2012;

b. Dengan cara pembelajaran yang sama seperti siklus II, tetapi peneliti dan guru Penjas lebih memperhatikan siswa dan menjaga agar siswa tetap fokus pembelajaran dan tidak cepat bosan, sehingga peneliti membebaskan siswa setelah 30 menit pembelajaran berlangsung, siswa-siswa diberi waktu untuk istirahat. Sehingga pembelajaran tidak membosankan, kemudian dimulai lagi kegiatan belajar mengajar SKJ 2012;

c. Peneliti selalu berpindah-pindah saat mengajar dengan mendekati siswa yang kurang bersemangat, guru sesekali berada di depan siswa dan sesekali berada di belakang maupun di tengah saat pembelajaran tersebut;

d. Peneliti dalam memberikan penjelasan harus dengan suara yang lantang atau keras sehingga semua anak dapat mendengar intruksi dengan jelas;

e. Peneliti memberikan penjelasan yang jelas dan benar saat di ruang kelas maupun saat di halaman, sehingga anak tidak merasa asing lagi;

f. Peneliti dan guru Penjas lebih perhatian kepada siswa yang masih belum bisa melakukan gerakan demi gerakan secara benar, sehingga peneliti dan kolaborator lebih bersifat pendekatan individual kepada siswa saat kegiatan belajar mengajar berlangsung;

g. Untuk menumbuhkan motivasi dan minat siswa dalam pembelajran SKJ 2012, guru Penjas dan peneliti selalu memberikan pujian kepada siswa yang sudah benar-benar bagus melakukan gerakan dan siswa yang belum bisa akan terus diberi motivasi, terkadang diberi penjelasan secara individu. 
Tahap perencanaan siklus III berdasarkan replaning siklus II meliputi kegiatan sebagai berikut:

a. Peneliti bersama guru Penjas merancang skenario pembelajaran SKJ 2012 yaitu gerakan Pendinginan dengan mengulang gerakan pemanasan dan gerakan Inti SKJ 2012 yang dipelajari pada siklus sebelumnya, dengan langkah-langkah sebagai berikut:

1) Peneliti menjelaskan mengenai materi yang akan diajarkan pada hari itu, siswa menyimak. Dengan kondisi kelas yang tenang sehingga siswa dapat dengan fokus melihat dan mengamati gerakan-gerakan yang baku dan benar pada video SKJ 2012 yang ditampilkan. Peneliti dengan menerangkan dan memperjelas lagi di depan kelas yaitu gerakan per gerakan saat Pendinginan SKJ 2012;

2) Peneliti memberikan contoh pembelajaran SKJ 2012 saat berada di halaman untuk praktik gerakan Pendinginan SKJ 2012. Siswa berbaris menurut absen dibagi menjadi $4 \mathrm{sab}$, sehingga peneliti dan guru Penjas dapat dengan mudah mengawasi siswa dan dapat hafal siswa yang sudah bisa dan siswa yang masih perlu bimbingan lebih atau masih kurang;

3) Peneliti dan siswa melakukan refleksi terhadap proses belajar mengajar yang telah dilakukan saat penutupan kegiatan pembelaajaran, yaitu dengan cara evaluasi dan peneliti mengadakan umpan balik untuk siswa tentang pembelajran yang dilakukan khususnya gerakan per gerakan dalam SKJ 2012;

b. Peneliti dan guru Penjas menyusun Rencana Pelaksanaan Pembelajaran (RPP) untuk materi yang berkaitan dengan pembelajran SKJ 2012, pada siklus III ini pembelajaran SKJ 2012 difokuskan pada gerakan Pendinginan terbagi menjadi lima gerakan;

c. Guru Penjas bersama peneliti menyiapkan media yang diperlukan dalam pembelajaran SKJ 2012 saat berada di kelas diantaranya yaitu, Laptop dan LCD. Disamping itu peneliti menyiapkan gambar-gambar maupun video lucu untuk ditampilkan setelah penerapan video SKJ 2012.

Pelaksanaan tindakan III ini direncanakan selama tiga kali pertemuan, yakni pada hari Jumat 19 April 2013; hari Jumat 26 April 2013; dan hari Jumat 3 Mei 2013 di SD Negeri I Panggung Barat Magetan. Masing-masing pertemuan dilaksanakan selama 2 × 35 menit. Dalam kegiatan ini peneliti menerapkan solusi yang telah disepakati dengan guru Penjas untuk mengatasi kekurangan pada proses pembelajaran SKJ 2012 dalam siklus II sebelumnya. Sesuai dengan skenario pembelajaran pada siklus III ini pembelajaran dilakukan oleh peneliti. Peneliti sekaligus melakukan observasi terhadap proses pembelajaran selama berlangsungnya kegiatan belajar mengajar dengan bantuan guru Penjas. Materi pelaksanaan tindakan III, pada pertemuan pertama di siklus III (Jumat, 19 April 2013) dimulai pada pukul 07.00 WIB ini adalah pembelajaran SKJ 2012 gerakan Pendinginan, sebelum masuk ke materi gerakan pendinginan siswa disuruh untuk melakukan gerakan pemanasan, dan inti terlebih dahulu, agar lebih hafal. Urutan pelaksanaan tindakan tersebut adalah:

a. Peneliti menerapkan video SKJ 2012 secara keseluruhan, siswa menyimak dengan seksama; 
b. Peneliti menjelaskan materi bersamaan dengan siswa sedang mengamati video yang ditampilkan, dengan tampilan gambar gerak dan penjelasan langsung diharapkan siswa dapat lebih paham dan jelas. Setelah selesai menampilkan gerakan secara keseluruhan SKJ 2012, kemudian peneliti menampilkan video lucu yang sudah peneliti siapkan, diharapkan siswa tidak merasa bosan dengan tampilan video SKJ 2012. Setelah itu peneliti menampilkan gerakan Pendinginan yang akan dipelajari pada pertemuan kali ini;

c. Peneliti memberi contoh gerakan atau demonstrasi gerakan saat semua siswa berada di luar kelas. Siswa mengulang gerakan Pemanasan dan Inti SKJ 2012 terlebih dahulu sebelum masuk ke gerakan Pendinginan SKJ 2012. Karena gerakan Pendinginan ini sama dengan gerakan Pemanasan saat Peregangan, jadi peneliti dapat dengan mudah menjelaskan kepada siswa;

d. Peneliti selalu berpindah-pindah tempat untuk dapat mengawasi dan melihat siswa saat pembelajaran dan dapat dengan langsung membenarkan jika ada siswa yang melakukan gerakan yang salah;

e. Peneliti memakai irama atau musik SKJ 2012 untuk menambah semangat siswa dan siswa dapat menyesuaikan dengan iringan musik dan mengikuti hitungan yang benar dalam SKJ 2012;

f. Siswa melakukan gerakan demi gerakan dengan semangat karena peneliti tidak melatih mereka tetapi memberikan hal baru dalam pembelajaran dengan konsep penerapan video SKJ 2012 dan praktik di lapangan secara langsung. Peneliti tidak memaksakan kepada siswa untuk tetap fokus saat pembelajaran SKJ 2012, terkadang peneliti memberi jeda waktu kepada siswa untuk istirahat, sehingga siswa tidak mudah bosan. Setelah jeda sejenak barulah dimulai lagi pembelajaran SKJ 2012, siswa sudah kembali fokus lagi;

g. Peneliti selalu menanyakan kepada siswa apakah ada yang merasa kesulitan saat pembelajaran SKJ 2012, terutama saat melakukan gerakan. Peneliti tetap menjaga komunikasi dengan siswa, apabila ada yang merasa kesulitan peneliti maupun guru Penjas langsung mendekat dan membenarkan gerakan siswa tersebut.

Materi pada pelaksanaan tindakan III, pada pertemuan kedua (Jumat, 26 April 2013) pukul 07.00 WIB dengan durasi waktu normal yaitu 2 x 35 menit. Urutan pelaksanaan tindakan tersebut adalah:

a. Peneliti tetap menerapkan video SKJ 2008 dari gerakan pemanasan, gerakan Inti, dan gerakan Pendinginan siswa menyimak dengan seksama. Terkadang peneliti bertanya kepada siswa apakah ada yang tidak tahu tentang gerakan tersebut. Untuk tetap menumbuhkan suasana senang dan bersemangat peneliti menampilkan video maupun gambar-gambar lucu, agar siswa merasa senang tidak mudah bosan;

b. Peneliti memberi contoh gerakan atau demonstrasi gerakan saat semua siswa berada di luar kelas. Siswa mengulang gerakan SKJ 2008 secara keseluruhan memakai iringan musik;

c. Peneliti selalu berpindah-pindah tempat untuk dapat mengawasi dan melihat siswa saat pembelajaran. Dan terkadang peneliti memimpin didepan agar siswa tahu urut-urtannya gerakan SKJ 2008, karena siswa masih belum hafal sepenuhnya; 
d. Dengan seringnya pengulangan gerakan SKJ 2008 diharapkan siswa akan lebih cepat hafal, dan dapat dengan benar melakukan gerakan yang baku. Dengan pengawasan peneliti dan guru Penjas, maka semua siswa dapat terkontrol dengan maksimal, sehingga kelihatan siswa yang sudah hafal dengan benar, siswa yang hafal tetapi masih ada gerakan yang salah, ataupun siswa yang belum hafal dan gerakan masih salah;

e. Peneliti tidak memaksakan kehendak kepada siswa, kalau harus hafal SKJ 2008 dengan baik dan benar. Peneliti hanya melaksanakan konsep yang telah disusun sebelumnya. Dengan memberi jeda istirahta kepada siswa setelah berulang-ulang melakukan SKJ 2008 itu adalah salah satu bentuk kelonggaran waktu dan aktifitas, sehingga siswa tidak merasa terbebani oleh pembelajaran SKJ 2008 ini.

Materi pada pelaksanaan tindakan III, pada pertemuan ketiga (3 Mei 2013) dilaksanakan kegiatan belajar mengajar sesuai jadwal setiap hari Jumat pagi dari pukul 07.00 WIB dengan durasi waktu selama 2 x 35 menit. Dalam pertemuan terakhir kali ini setelah melewati beberapa pertemuan disetiap siklusnya, peneliti masih melaksanakan konsep yang sama seperti pertemuan kemarin, yaitu masih mengulang gerakan SKJ 2012 secara keseluruhan dengan memakai iringan musik. Urutan pelaksanaan tindakan tersebut adalah:

a. Peneliti tetap menerapkan video SKJ 2012 dari gerakan pemanasan, gerakan Inti, dan gerakan Pendinginan siswa menyimak dengan seksama. Terkadang peneliti bertanya kepada siswa apakah ada yang tidak tahu tentang gerakan tersebut. Untuk tetap menumbuhkan suasana senang dan bersemangat peneliti menampilkan video maupun gambar-gambar lucu, agar siswa merasa senang tidak mudah bosan;

b. Peneliti memberi contoh gerakan atau demonstrasi gerakan saat semua siswa berada di luar kelas. Siswa mengulang gerakan SKJ 2012 secara keseluruhan memakai iringan musik;

c. Peneliti selalu berpindah-pindah tempat untuk dapat mengawasi dan melihat siswa saat pembelajaran. Dan terkadang peneliti memimpin didepan agar siswa tahu urut-urtannya gerakan SKJ 2012, karena siswa masih belum hafal sepenuhnya;

d. Peneliti tidak memaksakan kehendak kepada siswa, kalau harus hafal SKJ 2012 dengan baik dan benar. Peneliti hanya melaksanakan konsep yang telah disusun sebelumnya. Dengan memberi jeda istirahta kepada siswa setelah berulang-ulang melakukan SKJ 2012 itu adalah salah satu bentuk kelonggaran waktu dan aktifitas, sehingga siswa tidak merasa terbebani oleh pembelajaran SKJ 2012 ini;

e. Peneliti hanya menyuruh siswa untuk melakukan SKJ 2012 satu rangkaian penuh hanya sekali, selanjutnya peneliti menyuruh siswa untuk berkumpul dengan kelompok masing-masing. Secara bergantian masing-masing kelompok melakukan SKJ 2012 didepan semua teman-temannya, hingga jam pelajaran selesai.

Pengamatan dilakukan terhadap: (1) situasi belajar saat di kelas penerapan video SKJ 2012; dan (2) kemampuan siswa saat pelaksanaan gerakan SKJ 2012. Adapun instrumen yang digunakan peneliti dalam pengamatan adalah penilaian 
SKJ 2012. Hasil observasi aktifitas siswa dalam proses pembelajaran pada siklus III sudah dapat dikatakan berhasil dengan pemenuhan indikator target pencapaian pada siklus III yaitu 75\%. Target pencapaian dari 30 siswa adalah 25 siswa. Pada siklus III ini siswa-siswa yang sudah berhasil dengan sepenuhnya menguasai gerakan pemanasan SKJ 2012 sesuai dengan gerakan baku dan sudah hafal benar Hasil evaluasi keseluruhan pertemuan dari siklus III, bahwa murid-murid sudah memahami dan dapat melakukan SKJ 2012 dengan benar dan mendekati sempurna seperti contoh gerakan di video SKJ 2012. Sehingga siswa dapat merasa bangga karena keberhasilannnya sendiri mempelajari SKJ 2012 tiap tahap. Dan pada siklus III ini dengan target pencapaian 75\% sudah terpenuhi dari 30 siswa yang sudah melakukan gerakan benar dan hafal berjumlah 23 siswa. Hasil pada siklus III ini membuat peneliti semakin termotivasi untuk dapat membuat semua siswa melakukan gerakan SKJ 2012 secara benar, sedangkan dari pihak siswa merasa lebih unggul dari kelas VI atas keberhasilan mereka mempelajari gerakan SKJ 2012. Adapun keberhasilan dan kegagalan yang terjadi pada siklus III adalah:

a. Target pada siklus III yaitu 75\% dari 30 siswa adalah 23 siswa, sudah terpenuhi dan siswa yang sudah bisa melebihi target, yaitu sebanyak 25 siswa. Sehingga pemberian tindakan dicukupkan sampai siklus III ini;

b. Saat penerapan video SKJ 2012 di ruang kelas konsentrasi siswa sudah mulai fokus, mereka sudah mampu menangkap gerakan per gerakan dalam SKJ 2012;

c. Siswa sudah mampu melakasakan instruksi peneliti dan guru Penjas dengan bersungguh-sungguh. Dengan melihat siswa yang semakin bersemangat membuat peneliti lebih perhatian kepada semua siswa, sehingga komunikasi diantara peneliti dan siswa sangat baik. Disamping itu untuk menjaga komunikasi agar lebih baik lagi, peneliti selalu memberikan apresiasi berupa pujian: bagus, keren, nice, dengan mengacungkan jempol. Sehingga siswa merasa diperhatikan, kemudian mereka melakukan pembelajaran dengan senang gembira layaknya anak yang berusia 10 tahun;

d. Terdapat juga siswa yang masih kurang antusias terhadap pembelajaran SKJ 2012, karena merasa kurang percaya diri, jarang masuk saat pembelajaran SKJ 2012;

e. Berakhirnya pertemuan membuat siswa merasa kecewa, karena sudah tidak belajar SKJ 2012 lagi. Peneliti mempunyai konsep pembelajaran SKJ 2012 hanya menargetkan sampai tiga siklus saja, dimana terdapat 9x pertemuan atau tatap muka.

\section{PEMBAHASAN}

Proses pembelajaran SKJ 2012 dengan menerapkan video SKJ 2012 yang dilaksanakan pada kelas V SD Negeri 1 Panggung Barat Magetan pada siklus III. Siswa merespon dengan semangat dan antusias. Siswa sudah mulai tidak cepat bosan dengan penerapan video SKJ 2012. Kekurangan-kekurangan yang terjadi pada siklus sebelumnya telah dapat diatasi. Siswa yang pada awalnya kurang aktif, merasa tidak senang dan kurang antusias dalam pembelajaran SKJ 2012, akhirnya menjadi aktif dan lebih bersemangat ketika diberi penerapan video SKJ 2012. Guru Penjas dan peneliti telah mampu memancing respons siswa terhadap stimulus yang diberikannya. Siswa terlihat semangat untuk melakukan gerakan satu persatu maupun pertahap. Siswa sudah mampu melakukan gerakan SKJ 2012 
dengan benar walaupun kebenaran itu tidak sempurna, tetapi untuk siswa kelas $\mathrm{V}$ sudah sangat baik dan bagus, meskipun masih ada beberapa yang kurang baik. Berdasarkan hasil pelaksanaan tindakan pada siklus I, II, dan III dapat disimpulkan bahwa terjadi peningkatan gerakan SKJ 2012 dari awalnya yang masih banyak salah dan siswa belum hafal dengan lancar setelah melakukan beberapa action siswa menjadi lebih sedikit kesalahannya dan sebagian besar sudah menguasai SKJ 2012 secara keseluruhan.

Kondisi awal sebelum dilakukan Penelitian Tindakan Kelas (PTK) pada kelas V SD Negeri 1 Panggung Barat Magetan pembelajaran SKJ 2012 masih monoton berpusat pada guru Penjas. Para siswa dihadapkan pada gerakan SKJ 2012 yang monoton tanpa arahan yang jelas dan benar mengakibatkan kesegaran jasmani dari tujuan utama dilakukan SKJ 2012 belum tercapai, sehingga tingkat hafalan gerakan SKJ 2012 siswa sangat rendah. Dengan penerapan video SKJ 2012 untuk meningkatkan gerakan SKJ pada siswa SD Negeri 1 Panggung Barat Magetan, ternyata siswa lebih antusias dan semangat dalam pembelajaran baik itu saat berada di ruang kelas maupun di halaman sekolah. Siswa merasa tertantang dan saling berlomba untuk menunjukkan kemampuannya.

Peneliti dengan menggunakan konsep yang tertuang dalam PTK ini dapat mengaktifkan siswa saat pembelajaran, sehingga siswa dapat berkonsentrasi secara maksimal. Dengan perencanaan tiga siklus dalam penelitian ini dan terdapat 9x pertemuan, untuk mengetahui tingkat kemampuan awal gerakan SKJ 2012 peneliti melakukan tes awal sebelum diadakannya action pembelajaran SKJ 2012 sesuai siklus. Hal ini dapat dilihat saat tes awal SKJ 2012 yang dilakukan siswa sebelum adanya action penelitian yaitu penerapan video SKJ 2012 dan sesudah penerapan video SKJ 2012 dengan melakukan beberapa kali pertemuan setiap siklusnya, kemudian diadakan diadakan tes akhir SKJ 2012 untuk mengetahui seberapa besar peningkatan gerakan SKJ siswa selama pembelajaran

Tes awal SKJ 2012 yang dilaksanakan pada hari Jumat 22 Februari 2013 bertempat di SD Negeri 1 Panggung Barat Magetan pukul 07.00 WIB. Tes akhir yang dilaksanakan setelah melakukan beberapa pertemuan dalam siklus pada hari Jumat 10 Mei 2013 pukul 07.00 WIB di SD Negeri 1 Panggung Barat Magetan. Berdasarkan tabel tersebut menunjukkan bahwa, penerapan video SKJ 2012 untuk meningkatkan gerakan SKJ sangat efektif digunakan saat pembelajaran senam baku. Karena siswa dapat mengetahui dengan jelas dan paham benar setiap gerakan, sehingga kesegaran jasmani dapat tercapai. Dengan demikian dapat disimpulkan bahwa, penerapan video SKJ 2012 untuk meningkatkan gerakan SKJ pada siswa kelas V SD Negeri 1 Panggung Kecamatan Barat Magetan terbukti dengan adanya peningkatan saat tes awal SKJ 2012 dilakukan dan hasil tes akhir SKJ 2012 yang menunjukkan peningkatan besar.

\section{E. SIMPULAN DAN SARAN}

Penelitian tindakan kelas yang dilaksanakan pada siswa kelas V SD Negeri 1 Panggung Barat Magetan dilaksanakan dalam tiga siklus. Setiap siklus terdiri atas empat tahapan, yaitu: (1) perencanaan; (2) pelaksanaan tindakan; (3) pengamatan/observasi tindakan; dan (4) refleksi terhadap tindakan. Berdasarkan analisis data yang telah dilakukan dan pembahasan, diperoleh simpulan penerapan video SKJ 2012 dapat meningkatkan gerakan SKJ siswa kelas V SD Negeri 1 Panggung Barat Magetan. Dari hasil analisis data tes SKJ 2012 yang dilaksanakan 
untuk mengetahui peningkatan gerakan SKJ 2012 secara benar dilakukan sebelum dan sesudah pelaksanaan siklus. Dari hasil analisis data secara deskriptif kualitatif diperoleh peningkatan gerakan SKJ 2012 pada siklus I, II, dan III, setiap siklus terdapat tiga pertemuan tindakan.

Pada siklus I pembelajaran SKJ 2012 penekanan pada gerakan Pemanasan dengan pengenalan gerakan Inti dan Pendinginan, pada akhir pertemuan siklus I diadakan uji keterampilan oleh siswa dalam melakukan SKJ 2012 secara keseluruhan. Diketahui pada siklus I ini mencapai tingkat keberhasilan sebesar 30\% dari 30 siswa yaitu sebanyak 9 siswa. Pada siklus II pembelajaran SKJ 2012 merupakan refleksi dari siklus I terdapat penambahan materi pada SKJ 2012. Pembelajaran SKJ 2012 pada siklus II ini penekanan pada gerakan Inti SKJ 2012 dengan mengulang gerakan Pemanasan dan pengenalan gerakan Pendinginan SKJ 2012, untuk mengetahui peningkatan gerakan maka diakhir pertemuan siklus II ini diadakan uji keterampilan yang dilakukan oleh siswa dalam pelaksanaan SKJ 2012 secara keseluruhan. Diketahui dalam siklus II ini mencapai tingkat keberhasilan sebesar $60 \%$ dari 30 siswa yaitu sebanyak 19 siswa. Pada siklus III pembelajaran SKJ 2012 merupakan refleksi siklus II yang terdapat penambahan materi pada SKJ 2012.

Pada siklus III ini penekanan pada gerakan Pendinginan SKJ 2012 dengan mengulang gerakan Pemanasan dan Inti SKJ 2012, untuk mengetahui peningkatan gerakan maka diakhir pertemuan siklus III ini diadakan uji keterampilan yang dilakukan oleh siswa dalam pelaksanaan SKJ 2012 secara keseluruhan. Diketahui dalam siklus III ini mencapai tingkat keberhasilan sebesar $75 \%$ dari 30 siswa yaitu sebanyak 23 siswa. Tetapi saat penilaian SKJ 2012 setelah pelaksanaan Siklus yang berhasil mempraktikkan gerakan SKJ 2012 secara benar dan hafal menjadi 25 siswa. Sehingga persentase capaian menjadi 80\% dari 30 siswa, lebih tinggi dari persentase capaian yang telah direncanakan pada siklus III. Dalam pelaksanaan PTK yang diakhiri dengan tes SKJ 2012 untuk mengetahui peningkatannya terdapat siswa yang masih belum berhasil dalam penguasaan gerakan SKJ 2012. Dari 30 siswa masih terdapat 6 siswa yang belum berhasil dalam SKJ 2012, dimana persentase dari jumlah siswa yaitu 19,4\% yang belum berhasil melakukan SKJ 2012 secara benar.

Berdasarkan hasil penelitian, saran yang diajukan adalah bagi guru hendaknya terus berusaha untuk meningkatkan kemampuannya dalam mengembangkan materi, menyampaikan materi, serta dalam mengelola kelas, sehingga kualitas pembelajaran yang dilakukannya dapat terus meningkat seiring dengan peningkatan kemampuan yang dimilikinya. Selain itu, guru hendaknya mau membuka diri untuk menerima berbagai bentuk masukan, saran, dan kritikan agar dapat lebih memperbaiki kualitas mengajarnya. Guru Penjas hendaknya lebih inovatif dalam menerapkan metode untuk menyampaikan materi pembelajaran dan menerapkan video saat pembelajaran senam hendaknya dicoba dalam pembelajaran Penjas sehingga dapat bermanfaat untuk meningkatkan hasil belajar anak didiknya dan siswa dapat memperoleh kebugaran jasmani yang sesungguhnya sebagai hasil olah raga. Bagi kepala sekolah hendaknya berusaha menyediakan fasilitas yang dapat mendukung kelancaran kegiatan belajar mengajar. 


\section{DAFTAR RUJUKAN}

Arsyad, A. 2004. Media Pembelajaran. Jakarta: PT Raja Grafindo Persada.

Depdiknas. 2007. Kurikulum Tingkat Satuan Pendidikan Standar Kompetensi dan Kompetensi Dasar Pendidikan Jasmani Olahraga dan Kesehatan. Jakarta: Depdiknas.

Deputi Bidang Pemberdayaan Olahraga. 2012. Panduan Gerak SKJ 2012. Jakarta: Deputi Bidang Pemberdayaan Olahraga Kementerian Negara Pemuda dan Olahraga.

Dimyati dan Mudjiono. 2006. Belajar dan Pembelajaran. Jakarta: PT Rineka Cipta.

Dinata, M. 2004. Senam Aerobik Peningkatan Kesegaran Jasmani. Lampung: Cerdas Jaya.

Gino, H. J., Suwarni, Suripto, Maryanto, dan Sutijan. 1998. Belajar dan Pembelajaran II. Surakarata: UNS Press.

Hamalik, O. 1980. Media Pendidikan. Bandung: Alumni.

Iskandar. 2009. Penelitian Tindakan Kelas. Cipayung-Ciputat: Gaung Persada (GP) Press.

Madya, S. 2009. Teori dan Praktik Penelitian Tindakan (Action Research). Bandung: Alfabeta.

Sadiman, A.S., Rahardjo, R., Haryono, A., dan Rahardjito. 2009. Media Pendidikan, Pengertian, Pengembangan, dan Pemanfaatannya. Jakarta: PT Raja Grafindo Persada.

Sagala, S. 2005. Konsep dan Makna Pembelajaran. Bandung: CV. Alfabeta.

Sudjana, N., dan Rivai, A. 2007. Teknologi Pengajaran. Bandung: Sinar Baru Algensindo.

Suherman, A. 2000. Dasar-dasar Penjaskes. Jakarta: Depdikbud. Direktorat Jenderal Pendidikan Dasar dan Menengah Bagian Proyek Penataran Guru SLTP Setara D-III.

Suharno. 1993. Metodologi Pelatihan. Yogyakarta: IKIP Yogyakarta.

Suharno, Sukardi, Chodijah, dan Suwalni. 1998. Belajar dan Pembelajaran II. UNS Press.

Sumantri, M. 2001. Strategi Belajar Mengajar. Bandung: CV Maulana. 
Suyati dan Margono, A. 1992. Teori dan Praktik Senam Dasar. Surakarta: UNS Press.

Trianto. 2007. Model-Model Pembelajaran Inovatif Berorientasi Konstruktif Konsep Landasan Teoritis dan Implementasinya. Jakarta: Prestasi Pustaka. 